\title{
A Review on the Self-Cleansing Design Criteria for Sewer System
}

\author{
Charles H.J. Bong \\ Department of Civil Engineering, Faculty of Engineering, Universiti Malaysia Sarawak, 94300, Kota Samarahan, Sarawak, \\ Malaysia
}

Date Received: $20^{\text {th }}$ July 2014

Date Published: $1^{\text {st }}$ October 2014

\begin{abstract}
Sediment deposits in sewer system had been known to have adverse effects on the hydraulic performance of the system and also on the environment. Thus, the need for sewer system to carry sediment has been recognized for many years and self-cleansing criteria have been proposed in the literature for design purposes. Conventionally, a minimum critical velocity or critical shear stress was specified and although this approach had been successful in many cases; it was appreciated that a minimum critical velocity or critical shear stress which is unrelated to the characteristics and concentration of the sediment or the hydraulic behavior of the sewer could not properly represent the ability of the sewer flows to transport sediments. A more viable approach for self-cleansing design is to incorporate some aspect of the sediment and sewer characteristics into the design criteria; hence, various self-cleansing design criteria for sewer have been proposed in the literature. This paper presents a review on the various self-cleansing design criteria for sewer and proposed some further studies that could be conducted to improve the existing self-cleansing design criteria.
\end{abstract}

Keywords: Sediment, Self-cleansing design, Sewer system

\section{INTRODUCTION}

CEDIMENT deposition in sewer system had caused many adverse effect such as reduction in hydraulic capacity and Nenvironmental pollution due to the high pollutant concentrations that might be released during the erosion of these deposition [1-3]. To reduce sediment deposition, sewer system has been designed to have self-cleansing properties. In the design for sewer system for the purpose of self-cleansing, the system must be able to transport sediment and the system is free from sediment deposit as much as possible. The Construction Industry Research and Information Association (CIRIA), UK defined self-cleansing for sewer design as "An efficient self-cleansing sewer is one having a sediment transport capacity that is sufficient to maintain balance between the amounts of deposition and erosion, with time-averaged depth of sediment deposit that minimizes the combined costs of construction, operation and maintenance" [4,5]. A search in the literature for self-cleansing design of sewer will generally categorizes the design concepts into three groups namely based on nondeposition of sediment; based on moving of existing sediment on sewer bed; and based on energy slope [6]. The design concepts in each group could be classified further into smaller groups as shown in Figure 1.

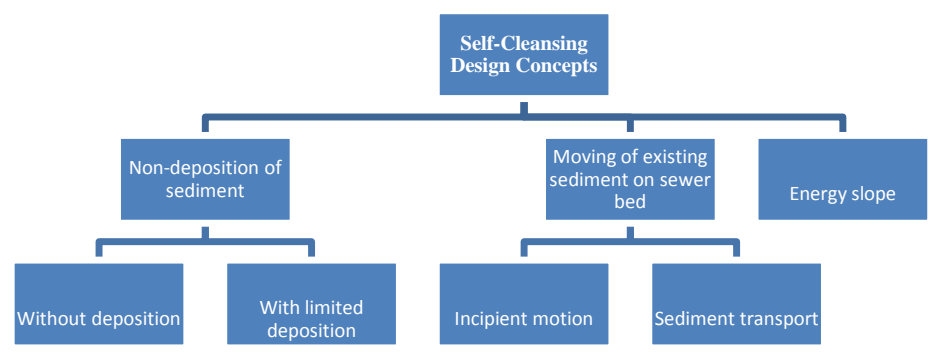

Figure 1 Classification of self-cleansing design concepts from the literature [6, 7]

C.H.J. Bong is with the Department of Civil Engineering, Faculty of Engineering, Universiti Malaysia Sarawak, 94300, Kota Samarahan, Sarawak, Malaysia (phone: +6082-583294; fax: +6082-583409; e-mail: bhjcharles@feng.unimas.my). 


\section{II.DESIGN CONCEPT BASED ON NON-DEPOSITION OF SEDIMENT}

In this design concept, conventionally the adoption of experience-based hydraulic criteria either minimum critical velocity or minimum critical shear stress is used. Minimum critical velocity $V_{c}$ is the most widely used design criteria for selfcleansing [4]. In the UK, two documents relevant to sewer design advocate the use of minimum critical velocity, namely "Sewers for adoption" by Water Services Association and "BS8005: Part 1: 1987: Sewerage - guide to new sewerage construction" by British Standard Institution [4]. The British Standard; BS8005 recommended a minimum critical velocity of $0.75 \mathrm{~m} / \mathrm{s}$ for storm sewer and $1.0 \mathrm{~m} / \mathrm{s}$ for combined sewer. In Malaysia, the minimum average flow velocity for open lined sewer shall not be less than $0.6 \mathrm{~m} / \mathrm{s}$ and restricted to a maximum of $2 \mathrm{~m} / \mathrm{s}$ as recommended by "Urban Stormwater Management Manual for Malaysia" [8] which was replaced later by "Urban Stormwater Management Manual for Malaysia $2^{\text {nd }}$ Edition" [9]. Earlier design manual, namely "Planning and Design Procedures No.1: Urban Drainage Design Standards and Procedures for Peninsular Malaysia" [10] recommended a minimum velocity of $0.9 \mathrm{~m} / \mathrm{s}$ and restricted to a maximum of $3 \mathrm{~m} / \mathrm{s}$. The minimum critical velocity value appears to have developed from experience without theoretical justification or underlying research [4]. The weakness of minimum critical velocity criteria is that it takes no account of the quantity or type of sediment to be transported or of other factors such as sewer size $[4,5]$. Table 1 gives a summary of available design criteria based on minimum critical velocity as adopted by different countries.

Table 1 Minimum critical velocity criteria [6, 7]

\begin{tabular}{|c|c|c|c|c|}
\hline Source & Country & Sewer type & $\begin{array}{l}\text { Minimum velocity } \\
(\mathrm{m} / \mathrm{s})\end{array}$ & Pipe flow condition \\
\hline \multirow[t]{2}{*}{ ASCE (1970) } & \multirow[t]{2}{*}{ USA } & Sanitary & 0.6 & Full/half full \\
\hline & & Storm & 0.9 & Full/half full \\
\hline \multirow{2}{*}{$\begin{array}{l}\text { British Standard } \\
\text { BS8005 (1987) }\end{array}$} & \multirow[t]{2}{*}{ UK } & Storm & 0.75 & Full \\
\hline & & Combined & 1.0 & Full \\
\hline \multirow{3}{*}{$\begin{array}{c}\text { Minister of Interior } \\
\text { (1977) }\end{array}$} & \multirow[t]{3}{*}{ France } & Sanitary & 0.3 & Mean daily \\
\hline & & Combined & 0.6 & $1 / 10$ full flow \\
\hline & & Separate & 0.3 & $1 / 100$ full flow \\
\hline $\begin{array}{c}\text { European Standard EN } \\
752-4 \text { (1997) }\end{array}$ & Europe & All sewers & $\begin{array}{c}0.7 \text { once/day for pipe } \\
\mathrm{D}<300 \mathrm{~mm} \\
0.7 \text { or more if } \\
\text { necessary for pipe } \mathrm{D} \\
>300 \mathrm{~mm}\end{array}$ & N/A \\
\hline Abwassertechnische & \multirow[t]{4}{*}{ Germany } & \multirow{4}{*}{$\begin{array}{l}\text { Sanitary } \\
\text { Storm } \\
\text { Combined }\end{array}$} & \multirow{4}{*}{$\begin{array}{l}\text { Depends on pipe } \\
\text { diameter ranging } \\
\text { from } 0.48(\mathrm{D}=150 \\
\mathrm{mm}) \text { to } 2.03(\mathrm{D}= \\
3000 \mathrm{~mm})\end{array}$} & \multirow{4}{*}{$\begin{array}{c}0.3 \text { to full; for } 0.1 \\
\text { to } 0.3 \text {, velocity plus } \\
10 \%\end{array}$} \\
\hline Verreinigung ATV, & & & & \\
\hline $\begin{array}{l}\text { Standard A } 110(1998) \\
\text { replaced by ATV- }\end{array}$ & & & & \\
\hline $\begin{array}{c}\text { DVWK-Regelwerk } \\
\text { (2001) }\end{array}$ & & & & \\
\hline Almedeij (2012) & Kuwait & Storm & 0.75 & $\begin{array}{l}\text { Rectangular open } \\
\text { channel }\end{array}$ \\
\hline DID (1975) & Malaysia & Storm & 0.9 & Lined channel \\
\hline $\begin{array}{c}\text { DID (2000) replaced by } \\
\text { DID (2012) }\end{array}$ & Malaysia & Storm & 0.6 & Open lined sewer \\
\hline
\end{tabular}

Minimum critical shear stress value $\tau_{c}$ which is considered to be more closely related to the forces causing sediment movement is sometimes used instead of minimum critical velocity criteria. Minimum critical shear stress criteria is used in some European countries and is also implicit in certain traditional UK criteria [4]. Same with the case for minimum critical velocity, the use of single minimum critical shear stress value is unrelated to the type and quantity of sediment entering the sewer. Table 2 gives a summary of available design criteria based on minimum critical shear stress criteria used in various countries. Rather than just using a single value, the non-deposition design concept was further modified to use more parameters in the 1990s which resulted in the without deposition design criteria and with limited deposition design criteria [6]. 
UNIMAS e-Journal of Civil Engineering

Table 2 Minimum critical shear stress criteria [6]

\begin{tabular}{ccccc}
\hline Source & Country & Sewer type & $\begin{array}{c}\text { Minimum shear } \\
\text { stress }\left(\mathrm{N} / \mathrm{m}^{2}\right)\end{array}$ & $\begin{array}{c}\text { Pipe flow } \\
\text { condition }\end{array}$ \\
\hline Lysne (1969) & USA & & $2.0-4.0$ & \\
ASCE (1970) & USA & Storm & $3.0-4.0$ & \\
Yao (1974) & USA & Sanitary & $1.0-2.0$ \\
Maguire rule (CIRIA & UK & & 6.2 & Full/half full \\
1986) & Norway & Combined & $3.0-4.0$ & \\
Lindholm (1984) & Separate & All & $1.0-1.5$ & 1.5 if sand is \\
present
\end{tabular}

\section{A. Without Deposition Design Criteria}

This is a conservative design criteria where the sewer is designed with no sediment deposit. In this design criteria, the mode of transport must be identified; either as suspended load or bed load in order to use an existing self-cleansing equation [6]. Suspended load travels at almost the same velocity with surrounding water and the shape of the vertical profile depends on the parameter $u_{*} / W_{s}$ where $W_{s}$ is the fall velocity of the sediment $[\mathrm{m} / \mathrm{s}]$ and $u_{*}$ is the shear velocity of the flow [m/s] defined as:

$u_{*}=\sqrt{\left(\frac{\tau_{c}}{\rho}\right)}$

where $\tau_{c}$ is the critical shear stress $\left[\mathrm{N} / \mathrm{m}^{2}\right]$ and $\rho$ is the density of liquid $\left[\mathrm{kg} / \mathrm{m}^{3}\right]$. For flow conditions and sediment particles that give values of $u_{*} / W_{s}<0.75$, the movement will be mainly as bed load; while for $u_{*} / W_{s}>0.75$, the sediment moves in suspension [11]. The point of transition is termed limit of deposition.

For bed load transport, May et al. [11] combined seven formulas from different experimental laboratory test and obtained:

$C_{v}=3.03 \times 10^{-2}\left(\frac{D^{2}}{A}\right)\left(\frac{d_{50}}{D}\right)\left[1-\frac{V_{c}}{V_{L}}\right]\left[\frac{V_{L}^{2}}{g D(s-1)}\right]^{1.5}$

$V_{c}=0.125\left[g(s-1) d_{50}\right]^{0.5}\left[\frac{y}{d_{50}}\right]^{0.47}$

where $C_{v}$ is volumetric sediment concentration $[\mathrm{ppm}] ; D$ is pipe diameter $[\mathrm{m}] ; A$ is flow area cross-section $\left[\mathrm{m}^{2}\right] ; d_{50}$ is median particle size larger than $50 \%$ by mass $[\mathrm{m}] ; V_{c}$ is critical velocity $[\mathrm{m} / \mathrm{s}] ; V_{L}$ is self-cleansing velocity $[\mathrm{m} / \mathrm{s}] ; g$ is acceleration due to gravity $\left[\mathrm{m}^{2} / \mathrm{s}\right] ; s$ is specific gravity for sediment and $y$ is water depth [m]. May et al. [11] claimed (2) and (3) are best fit for 332 individual laboratory tests. The laboratory tests conditions covered by the data included: pipe diameters from $77 \mathrm{~mm}$ to $450 \mathrm{~mm}$; sediment size from $160 \mu \mathrm{m}$ to $8300 \mu \mathrm{m}$; flow velocities from $0.24 \mathrm{~m} / \mathrm{s}$ to $1.5 \mathrm{~m} / \mathrm{s}$; proportional flow depth $\left(\frac{y}{D}\right)$ from $0.16 \mathrm{~m}$ to $1 \mathrm{~m}$; and sediment concentrations from $2.3 \mathrm{ppm}$ to $2110 \mathrm{ppm}$. During bed load transport, sediment particles move much slower relative to the flow than those carried in suspension. A study on particle velocity in sediment transport over clean fixed bed has shown that the sediment particle velocity, even for the fastest moving 
particle is as low as about half of the mean flow velocity [12]. For suspended load, (4) was plotted by Macke [13] with data from other studies [14-16].

$C_{v}=\frac{\lambda_{0}^{3} V_{L}^{5}}{30.4(s-4) W_{s}^{1.5} A}$

where $C_{v}$ is volumetric sediment concentration $[\mathrm{ppm}] ; \lambda_{0}$ is the Darcy-Weisbach friction factor; $W_{s}$ is the fall velocity $[\mathrm{m} / \mathrm{s}] ; A$ is flow area cross-section $\left[\mathrm{m}^{2}\right] ; s$ is specific gravity for sediment and $V_{L}$ is self-cleansing velocity [m/s]. Equation (4) is based on experiments for sediment diameter from $0.16 \mathrm{~mm}$ to $0.37 \mathrm{~mm}$; pipe diameters of $192 \mathrm{~mm}, 290 \mathrm{~mm}$ and 445 $\mathrm{mm}$; sediment concentrations from $3 \mathrm{ppm}$ to $1700 \mathrm{ppm}$ and is valid beyond bed shear stress of $1.07 \mathrm{~N} / \mathrm{m}^{2}$ [13].

\section{B. With Limited Deposition Design Criteria}

Compares to the design criteria without deposition mentioned earlier, design criteria with limited deposition gives less conservative design in terms of milder slope for both bed load and suspended load. This design criteria allows for small sediment deposition at the bottom of sewer, thus reduces the sewer slope. The presence of a limited depth of sediment deposit to the invert of the sewer reduced the slope requirement over entire range of sewer diameter [17]. However, this design criteria requires careful operation and maintenance of the sewer system since the condition is very close to critical condition.

A design chart such as the one shown in Figure 2 was developed by the Construction Industry Research and Information Association (CIRIA), UK based on the concept of non-deposition which incorporate the concept of limited deposition with allowable $2 \%$ of deposition depth. The design chart attempts to relate minimum velocity with the pipe size and roughness, proportional flow depth, sediment size and specific gravity, degree of cohesion between particles, sediment load or concentration and the presence of deposited bed [5]. The weakness of the CIRIA approach is that it is an envelope approach based on full pipe velocities and as such does not acknowledge actual design minimum flow rates [18].

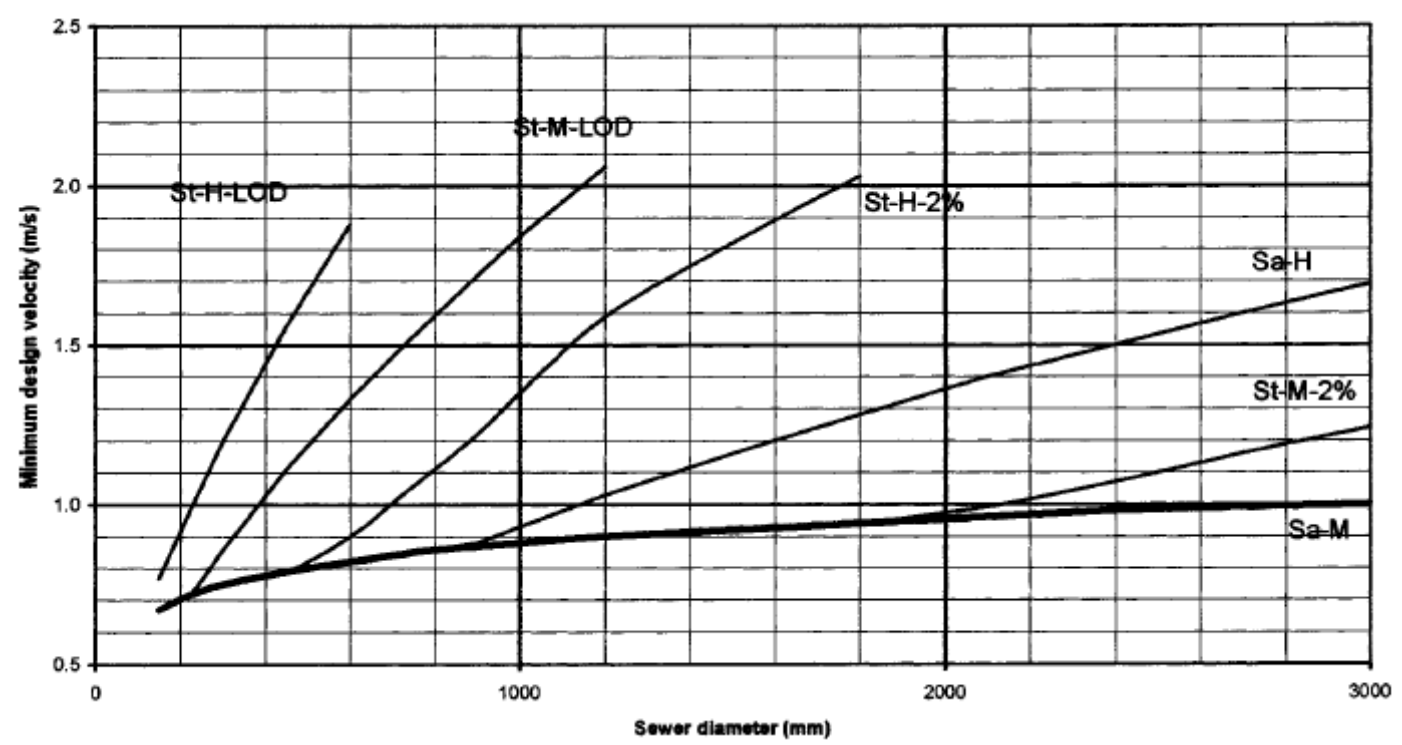

Figure 2 Minimum design velocities by simplified construction industry research and information association procedure. Sewer types: $\mathrm{Sa}=$ sanitary and $\mathrm{St}=$ storm; Sediment loads: $\mathrm{M}=$ medium, and $\mathrm{H}=$ high; Deposition criteria: LoD = limit-ofdeposition and $2 \%=$ allowable deposition depth [5]

\section{DeSign CONCEPT B ASED On MOVIng OF EXISTING SEDIMENT ON SEWER BeD}

Under this design concept, further classification could be made into two groups; namely incipient motion and sediment transport. This design concept assumed that the sediment already deposited on sewer bed. The equations developed under this design concept take into account some aspect of sediment and channel characteristics so as to start moving the existing deposited sediment. 


\section{UNIMAS e-Journal of Civil Engineering}

\section{A. Moving of Existing Sediment on Sewer Bed Based on Incipient Motion}

Recognizing that single minimum critical value criteria is not adequate for self-cleansing design, several researchers have studied incipient motion over rigid bed [19-23] and developed incipient motion equations that incorporate some aspect of sediment and channel characteristics. All the incipient motion equations developed by these researchers are in the form of:

$$
\frac{V_{c}}{\sqrt{g d_{50}(s-1)}} a\left(\frac{d_{50}}{R}\right)^{b}
$$

where $V_{c}$ is critical velocity $[\mathrm{m} / \mathrm{s}] ; g$ is acceleration due to gravity $\left[\mathrm{m}^{2} / \mathrm{s}\right] ; d_{50}$ is sediment median diameter [m]; $s$ is specific gravity for sediment; $R$ is hydraulic radius; $a$ and $b$ are coefficients. However, some existing literature for rigid bed channel has shown that the incipient motion equation in the form of (5) become less accurate as the sediment deposit thickness increased [24] due to changes in the hydraulic of the channel by the sediment deposits where the flow would assume a new depth above the deposited bed [25]. Thus, in recent development, the sediment deposit thickness has been suggested to be incorporated into (5) [26]. For very thick sediment deposition, the incipient motion condition is similar to that of loose boundary channel and (6) by Shields [27] could be used for self-cleansing design purposes.

$$
\theta_{c}=\frac{\tau_{c}}{g d_{50}\left(\rho_{s}-\rho\right)}
$$

where $\theta_{c}$ is the dimensionless Shields stress; $\tau_{c}$ is the critical shear stress $\left[\mathrm{N} / \mathrm{m}^{2}\right] ; g$ is the acceleration due to gravity $\left[\mathrm{m} / \mathrm{s}^{2}\right] ; \rho_{s}$ is the sediment density $\left[\mathrm{kg} / \mathrm{m}^{3}\right] ; \rho$ is the fluid density $\left[\mathrm{kg} / \mathrm{m}^{3}\right]$ and $d_{50}$ is the sediment median diameter $[\mathrm{m}]$ [27].

\section{B. Moving of Existing Sediment on Sewer Bed Based on Sediment Transport}

As for the sediment transport design criteria, researchers have derived equations for velocity required to scour bed deposit on rigid beds $[16,19,28]$. Most of these sediment transport equations are in the form of:

$$
\frac{V_{s}}{\sqrt{g d_{50}(s-1)}}=a C_{v}^{b}
$$

where $V_{s}$ is scour velocity $[\mathrm{m} / \mathrm{s}] ; g$ is acceleration due to gravity $\left[\mathrm{m}^{2} / \mathrm{s}\right] ; d_{50}$ is sediment median diameter [m]; $s$ is sediment specific gravity; $C_{v}$ is sediment volumetric concentration [ppm]; $a$ and $b$ are coefficients.

\section{DESIGN CONCEPT BASED ON ENERGy SLOPE}

In this design concept, the minimum sewer gradient $S_{0}$ is used as the criteria to avoid sediment deposition. This concept requires input parameters such as flow conditions, incoming sediment transport rate, sediment characteristics such as particle size and density; and hydraulic and pipe characteristics such as pipe geometry and hydraulic roughness [6]. Appropriate curves had been developed for calculating minimum sewer slope using tractive force design for self-cleansing [18] to be used for gravity sanitary sewer design in the United States as shown in Figure 3. A design chart relating the flow discharge with the sewer gradient and pipe diameter has been developed by Nalluri and Ab. Ghani [29] and as shown in Figure 4. 
UNIMAS e-Journal of Civil Engineering

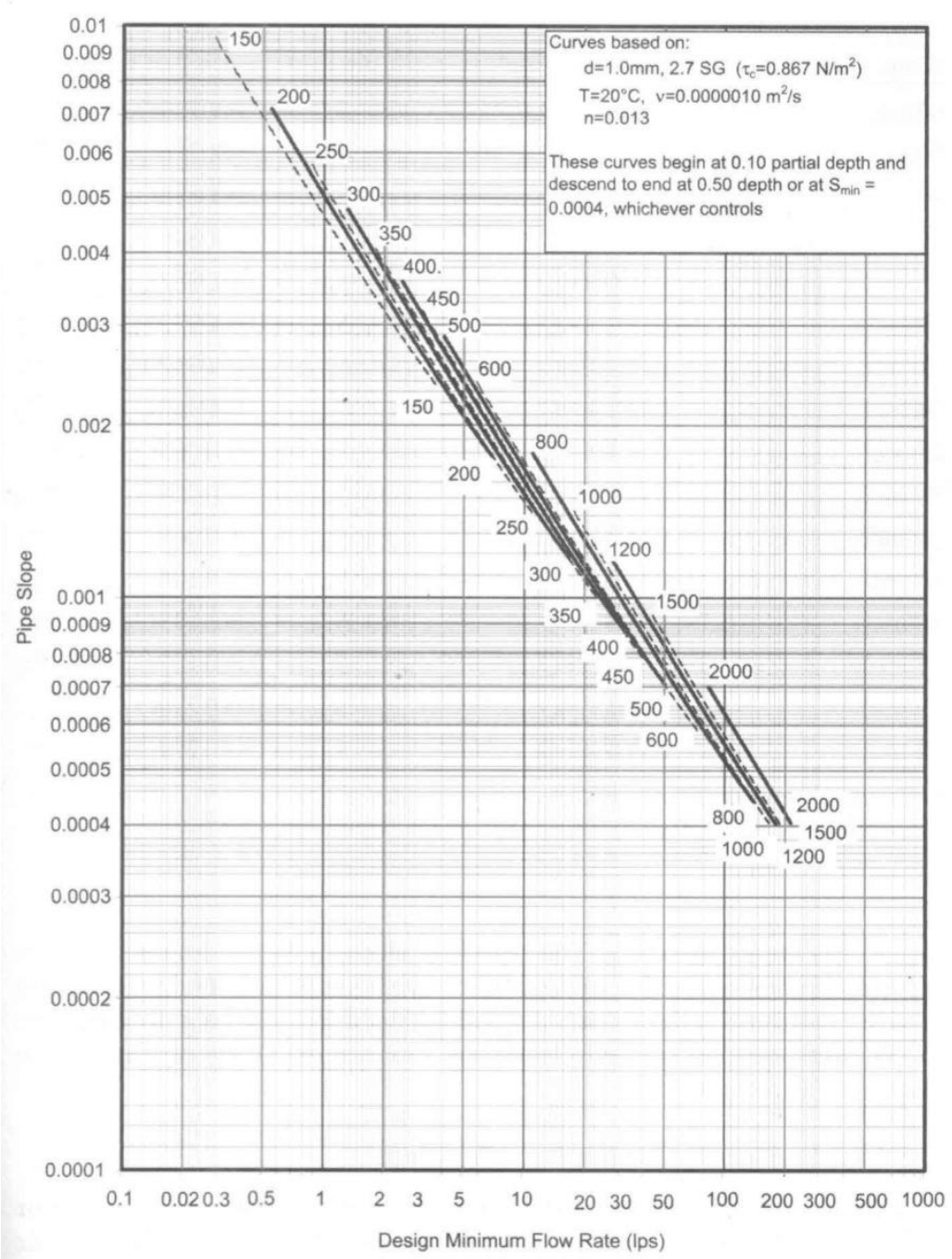

Figure 3 Self-cleansing slopes as a function of $Q_{\min }$ for Manning n $=0.013$ [18]

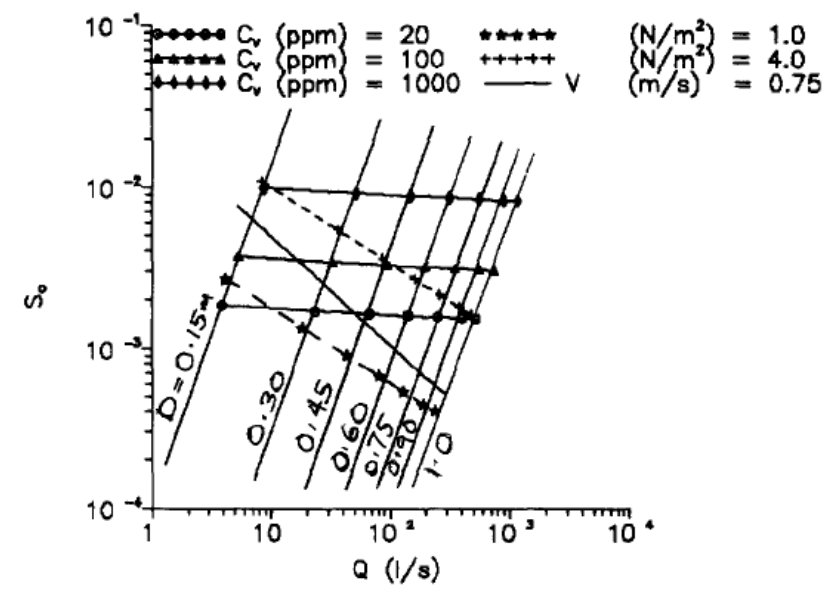

Figure $4 Q-S_{0}-D$ plot: clean pipe (half-full flow, $d_{50}=1.0 \mathrm{~mm}, k_{0}=0.6 \mathrm{~mm}$ ) [29] 


\section{CLOSURE}

Though a large number of researches and proposed criteria exist in the literature, many designers still prefer to use the adoption of a single minimum value of critical velocity or critical shear stress since these criteria are easy to use especially for a simple or small sewer system. A more viable approach for self-cleansing design is through the use of incipient motion equations which incorporate some aspect of the sediment and sewer characteristics. However, since most of the incipient motion equations were developed under controlled conditions in laboratory flumes; further studies are needed to better understand the representative particle size of sediment and sewer characteristics on-site. Experimental study for incipient motion of thicker sediment deposition could be conducted to determine at which sediment thickness the sewer bed will start to behave in similar manner to loose boundary bed. Moreover, little consistent data are available in the literature on sediment characteristics in developing countries that use open sewer system [30]. Therefore, further studies are encouraged on aforementioned cases so as to provide valuable information to improve the existing self-cleaning design criteria for sewer.

\section{REFERENCES}

[1] R. M. Ashley, D. J. J. Wotherspoon, B. P. Coghlan, and I. McGregor, "The erosion and movement of sediments and associated pollutants in combined sewers," Water Science and Technology, vol. 25, pp. 101 - 114, 1992.

[2] A. N. A. Schellart, S. J. Tait, and R. M. Ashley, "Estimation of uncertainty in long-term sewer sediment predictions using a response database," Journal of Hydraulic Engineering, vol. 136, pp. 403-411, 2010.

[3] J. P. Rodríguez, N. McIntyre, M. Diaz-Granados, and Č. Maksimović, "A database and model to support proactive management of sedimentrelated sewer blockages," Water Research, vol. 46, pp. 4571-4586, 2012.

[4] D. Butler, R. May, and J. Ackers, "Sediment transport in sewers part 2: design," Proc. Instn Civ. Engrs Wat., Marit. \& Energy, vol. 118, pp. 113$120,1996$.

[5] D. Butler, R. May, and J. Ackers, "Self-cleansing sewer design based on sediment transport principles," Journal of Hydraulic Engineering, vol. 129, pp. 276-282, 2003.

[6] N. Vongvisessomjai, T. Tingsanchali, and M. S. Babel, "Non-deposition design criteria for sewers with part-full flow," Urban Water Journal, vol. 7, pp. 61-77, 2010

[7] C. H. J. Bong, "Self-cleansing urban drain using sediment flushing gate based on incipient motion," Ph.D dissertation, Universiti Sains Malaysia, 2013.

[8] DID, "Urban Stormwater Management Manual for Malaysia," Kuala Lumpur, Malaysia: Department of Irrigation and Drainage, Malaysia, 2000.

[9] DID, "Urban stormwater management manual for Malaysia - 2nd edition," Kuala Lumpur, Malaysia: Department of Irrigation and Drainage, Malaysia, 2012

[10] DID, "Planning and design procedures no.1: urban drainage design standards and procedures for Peninsular Malaysia," Kuala Lumpur, Malaysia, 1975 .

[11] R. W. P. May, J. C. Ackers, D. Butler, and J. Sian, "Development of design methodology for self-cleansing sewers," Water Science and Technology, vol. 33, pp. 195-205, 1996.

[12] J. J. Ota and G. S. Perrusquia, "Particle velocity and sediment transport at the limit of deposition in sewers," Water Science and Technology, vol. 67, pp. 959-967, 2013.

[13] E. Macke, "About sediment at low concentrations in partly filled pipes," Leichtweiss Institut Fur Wasserbau Der Technischen, Universitat Braunschweig, 1982.

[14] R. Durand, "Basic relationships of the transport of solids in pipes; experiment research," in Minnesota International Hydraulics Convention, Minneapolis, 1953, pp. 89-103.

[15] H. A. Einstein and N. Chein, "Effects of heavy sediment concentration near the bed on velocity and sediment distribution," Omaha: Army Engineering Division, 1955.

[16] M. P. Robinson and W. H. Graf, "Pipelines of low concentration sand-water mixtures," Journal of Hydraulic Division, vol. 98, pp. 1221-1241, 1972 .

[17] C. Nalluri, A. A. Ghani, and A. K. S. El-Zaemey, "Sediment transport over deposited beds in sewers," Water Science and Technology, vol. 29, pp. $125-133,1994$

[18] P. Bizier, (Ed.), Gravity sanitary sewer design and construction. Reston, Virginia: American Society of Civil Engineers (ASCE), 2007.

[19] J. P. Craven, "The transportation of sand in pipes; free-surface flow," presented at the Hydraulics Conference Proceedings, State University of Iowa Studies in Engineering, Iowa, 1953.

[20] P. Novak and C. Nalluri, "Sediment transport in smooth fixed bed channels," Journal of the Hydraulics Division, vol. 101, pp. 1139 - 1154, 1975.

[21] S. I. A. Ojo, "Study of incipient motion and sediment transport over fixed beds," Ph.D dissertation, Department of Civil Engineering, University of Newcastle upon Tyne, 1978.

[22] P. Novak and C. Nalluri, "Incipient motion of sediment particles over fixed beds," Journal of Hydraulic Research, vol. 22 , pp. 181 - 197, 1984.

[23] A. K. S. El-Zaemey, "Sediment transport over deposited bed sewers," Ph.D dissertation, Department of Civil Engineering, University of NewCastle upon Tyne, 1991.

[24] A. Ab. Ghani, A. M. Salem, R. Abdullah, A. S. Yahaya, and N. A. Zakaria, "Incipient motion of sediment particles over deposited loose beds in a rectangular channels," presented at the 8th International Conference on Urban Storm Drainage, Sydney, Australia, 1999.

[25] C. Nalluri and W. Dabrowski, "Need for new standards to prevent deposition in wastewater sewers," Journal of Environmental Engineering, vol. 120, pp. 1032-1042, 1994.

[26] C. H. J. Bong, T. L. Lau, and A. Ab. Ghani, "Verification of equations for incipient motion studies for a rigid rectangular channel," Water Science and Technology, vol. 67, pp. 395-403, 2013.

[27] A. Shields, "Anwendung der ahnlichkeitsmechanik und der turbulentzforschung auf die geshiebebewegung," PhD dissertation, Mitt. Preuss. Versuchsanst. Wasserbau Schiffbau, 1936.

[28] T. R. Camp, "Minimum velocities for sewers final report committee to study limiting velocities of flow in sewers," Journal of Boston Society of Civil Engineers, vol. 29, 1942.

[29] C. Nalluri and A. Ab. Ghani, "Design options for self-cleansing storm sewers," Water Science and Technology, vol. 33, pp. 215-220, 1996.

[30] R.M. Ashley., J.-L. Bertrand-Krajewski, T. Hvitved-Jacobsen, and M. Verbanck, (Eds.), Solids in sewers - characteristics, effects and control of sewer solids and associated pollutants. Caxton Street, London: IWA Publishing, 2004. 